\title{
Chemical phosphate removal from Hartbeespoort Dam water, South Africa
}

\author{
KPT Atta', JP Maree ${ }^{2,4}$, MS Onyango ${ }^{1}$, L Mpenyana-Monyatsi $^{3}$ and M Mujuru ${ }^{4}$ \\ 'Department of Chemical Engineering, Faculty of Engineering, Tshwane University of Technology, Private Bag X680, \\ Pretoria, 0001, South Africa \\ ${ }^{2}$ ROC Water Technologies, PO Box 70075, Die Wilgers, Pretoria, 0041, South Africa \\ ${ }^{3}$ Department of Environmental, Water and Earth Sciences, Faculty of Science, Tshwane University of Technology, Private Bag X680, \\ Pretoria, 0001, South Africa \\ ${ }^{4}$ Department of Water \& Sanitation, Faculty of Science \& Agriculture, University of Limpopo, Private Bag X1106, Sovenga 0727, \\ South Africa
}

Phosphate is one of the major nutrients contributing to the increased eutrophication of lakes and natural waters. The feed water to the Hartbeespoort Dam amounts to $650 \mathrm{ML} / \mathrm{d}$ of mainly treated sewage. Phosphate levels in the dam water need to be lowered from the current $0.2 \mathrm{mg} / \mathrm{L}$ to less than $0.05 \mathrm{mg} / \mathrm{L}$ to control eutrophication. Chemicals such as iron(III), iron(II), aluminium(III) and lime can be used to precipitate phosphate as $\mathrm{FePO}_{4}, \mathrm{Fe}_{3}\left(\mathrm{PO}_{4}\right)_{2}, \mathrm{AlPO}_{4}$ and $\mathrm{Ca}_{3}\left(\mathrm{PO}_{4}\right)_{2}$, respectively. OLI software was used to identify the most suitable chemical for phosphate removal. It was found to be $\mathrm{Ca}(\mathrm{OH})_{2}$ as this only requires the $\mathrm{pH}$ to be raised to 9.5. $\mathrm{FeCl}_{3}, \mathrm{FeCl}_{2}$ and $\mathrm{AlCl}_{3}$ were found to be unsuitable due to the required $\mathrm{pH}$ and/or the extent to which they could remove phosphate. For lowering of phosphate levels from $0.2 \mathrm{mg} / \mathrm{L}$ (as $\mathrm{P}$ ), the current concentration in the Hartbeespoort Dam water, to $<0.05 \mathrm{mg} / \mathrm{L}$ (as P), the minimum concentration that is needed to support algal growth, a lime dosage of $50 \mathrm{mg} / \mathrm{L}$ is required. The cost of lime treatment will amount to $0.15 \mathrm{ZAR} / \mathrm{m}^{3}$. It is thus recommended that eutrophication in the Hartbeespoort Dam be controlled by removal of phosphate through lime dosing.

\section{INTRODUCTION}

All lifeforms require the element phosphorus in the form of phosphate. Phosphate has a critical role in RNA and DNA synthesis and in cellular metabolism. Every year, China, the United States, Morocco, South Africa and other countries mine millions of tonnes of phosphate. The bulk of the phosphate is turned into fertilizers for the production of food crops. In many countries, including South Africa, phosphate is a limiting plant nutrient which must be supplemented in the soil, and farmers add phosphate-based fertilizers to their soils to increase agricultural yields. Agriculture has led to a global phosphate-mining industry whose sales amount to tens of billions of US dollars. However, such deposits are finite resources that could be depleted within the $21^{\text {st }}$ century (Herring and Fantel, 1993).

Around 2008 the US Geological Survey (USGS) estimated that around 62 billion tonnes of phosphate remained in the ground globally. This included 15 billion tonnes of deposits that were mineable at that time and others that were not being exploited. The latter deposits are left un-mined mainly because they contain too many toxic impurities such as cadmium and other toxic metals or because they are offshore in difficult-to-reach places (USGS, 2009).

The demand for fertilizers is predicted to grow by $2.5-3 \%$ per year, at which rate of exploitation the world's reserves should last for around 125 years. Faster growth in demand for fertilizers would deplete phosphate reserves even quicker. The increased use will be driven partly by the rising global population, which will require food production to at least double by 2050, according to the Food and Agricultural Organization of the United Nations (FAO) (FAO, 2018).

In the face of dwindling, finite global phosphate resources, recovery of phosphates using technologies such as those proposed in this paper will also help to reduce eutrophication of lakes Humans create huge volumes of wastewater through inefficiencies and poor management of water systems and this wastewater poses sustainability challenges, depletes energy reserves and undermines human water security and ecosystem health. Technologies, such as examined in this study, allow a more efficient management and use of scarce freshwater sources. (Stanley et al., 2012).

It is estimated that sewage treatment plants discharge a total of $650 \mathrm{ML} / \mathrm{d}$ of treated sewage into the Hartbeespoort Dam catchment (Creamer, 2012; Annandale, et al., 2011). Other effluents impounded by the dam are from informal settlements, agricultural runoff, stormwater from industrial sites, NECSA and acid mine drainage, since mine-water started to decant at 18 Winze in the Western Basin in 2002. A consequence of receiving sewage, industrial effluents and stormwater is that these carry dissolved nutrients in the form of phosphate and nitrogen which stimulate algal growth. The depletion of nutrients in the dam water results in periodic die-off of algae and water hyacinth, resulting in the dam's hypertrophic state.

The Hartbeespoort Dam has a surface area of $20 \mathrm{~km}^{2}$, a maximum capacity of $195000000 \mathrm{~m}^{3}$ and a mean depth of $9.6 \mathrm{~m}$. The maximum depth is $45 \mathrm{~m}$. It is linked to the Vaal River system as some of its

\section{CORRESPONDENCE}

M Mujuru

\section{EMAIL}

munyaradzi.mujuru@ul.ac.za

\section{DATES}

Received: 22 September 2019

Accepted: 6 October 2020

\section{KEYWORDS}

eutrophication water hyacinth cyanobacteria sediments algae lime ferric chloride aluminium chloride ferrous chloride

\section{COPYRIGHT}

(c) The Author(s) Published under a Creative Commons Attribution 4.0 International Licence (CC BY 4.0) 
feed water is channelled via the Rand Water distribution system, south of Johannesburg. The Vaal River system, through sewage treatment plants, is linked to the Crocodile and Magalies Rivers that feed the Hartbeespoort catchment areas. Hartbeespoort Dam water is used for irrigation of $160 \mathrm{~km}^{2}$ of farmland, on which tobacco, wheat, lucerne, fruit and flowers are produced. The water is used for drinking in the towns of Hartbeespoort, Schoemansville, Kosmos and Ifafi. The water is also used as industrial water and for aquaculture. The dam is popular for angling, water sport and recreational activities.

Scientific studies (Mitchell and Crafford, 2016; Chutter and Rossouw, 1992) have shown that phosphate levels in the Hartbeespoort Dam should be reduced from $0.2 \mathrm{mg} / \mathrm{L}$ to less than $0.05 \mathrm{mg} / \mathrm{L}$ in order to curb algal growth (Venter, 2004). An attempt has been made to control eutrophication in the dam by using: (i) a biological remediation programme; (ii) floating wetlands; (iii) fish management; (iv) sediment removal; and (v) algal harvesting (Venter, 2004). The fact that the water body still contains $0.2 \mathrm{mg} / \mathrm{L}$ phosphate (total of $20 \mathrm{t} \mathrm{P}$ ), together with the phosphate-laden inflow water and the $180 \mathrm{t}$ of phosphate (as P) stored in the sediment, is an indication that these methods are inadequate. A solution to eutrophication would be the complete removal of nutrients from sewage treatment plant effluent and phosphate from non-point sources, such as informal settlements and agricultural run-off. Due to the shortage of technical experts in South Africa and the poor performance of many municipal wastewater treatment plants, the discharge from these plants often contributes further to eutrophication of water bodies. Several other large dams in South Africa are also heavily eutrophic, e.g., Rietvlei Dam, Pienaars River Dam, and the Vaal Barrage. Waters from eutrophic dams also contain cyanobacteria (Oberholster and Ashton, 2008) for which phosphate-rich sediment creates favourable conditions for growth. Cyanobacteria are responsible for the release of cyanotoxins, some of which are recognised to have caused the deaths of wild animals, farm livestock, pets, fish and birds in many countries (Holdsworth, 1991.

Chemical phosphate removal with iron-rich mine water, commercially available iron(III), iron(II) and aluminium(III) and $\mathrm{Ca}(\mathrm{OH})_{2}$ can be considered as low-cost solutions for phosphate removal. In the case of iron, it can also be generated electrolytically. The solubilities of $\mathrm{FePO}_{4}, \mathrm{Fe}_{3}\left(\mathrm{PO}_{4}\right)_{2}$ and $\mathrm{AlPO}_{4}$ have been determined as functions of $\mathrm{pH}$ (Ghassemi and Recht, 1971; Van der Merwe, et al., 1983. Fe(II) can remove phosphate in a narrow $\mathrm{pH}$ range around $\mathrm{pH} 8$, compared to the $\mathrm{pH}$ range of 4-6, for Fe(III) (Fig. 1). Solubility of inorganic phosphorus in aquatic systems is determined by the physico-chemical characteristics of the water. Diaz et al. (1994) conducted laboratory studies to determine the influence of $\mathrm{pH}$ and $\mathrm{Ca}$ on inorganic phosphate

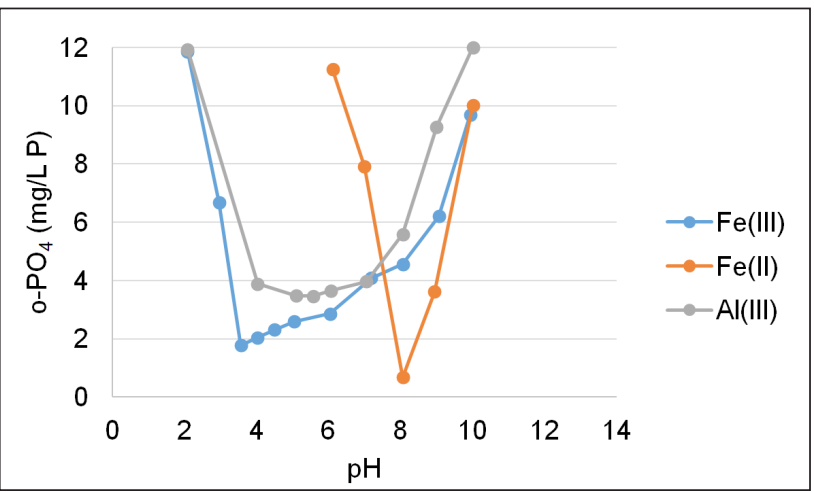

Figure 1. Precipitation of orthophosphate with $\mathrm{Fe}(\mathrm{II}), \mathrm{Fe}(\mathrm{III})$ and $\mathrm{Al}(\mathrm{III})$ at a cation to orthophosphate equivalent ratio of 1.0 (Ghassemi and Recht, 1971). Original orthophosphate concentration $=12 \mathrm{mg} / \mathrm{L} P$ (from $\mathrm{Na}_{2} \mathrm{HPO}_{4}$ ) precipitation and solubility relationships in water. They used water samples from selected streams and canals in south Florida, USA, and incubated them at $25^{\circ} \mathrm{C}$ in $2.8 \mathrm{~L}$ containers which were continuously stirred under different $\mathrm{pCO}_{2}$ levels. It was determined that precipitation of soluble $\mathrm{P}$ was influenced by the initial Ca concentration of the water. Precipitation of inorganic $\mathrm{P}$ increased at Ca levels above $100 \mathrm{mg} / \mathrm{L}$ and at $\mathrm{pH}>9.0$. Solubility of inorganic $\mathrm{P}$ in water decreased above $\mathrm{pH} 8.5$, and at $\mathrm{pH} 9.0$ at all Ca levels more than $60 \%$ of the soluble $\mathrm{P}$ was precipitated. However, P solubility at low Ca levels (20 and $50 \mathrm{mg} / \mathrm{L}$ ) was not affected at $\mathrm{pH}<9.0$. The decrease in $\mathrm{P}$ solubility as $\mathrm{pH}$ and $\mathrm{Ca}$ levels were increased suggests that calcium phosphate mineral formation occurred in stream and canal water.

Another important requirement for the removal of phosphate from Hartbeespoort Dam water is the removal of sediment which has trapped an estimated $180 \mathrm{t}$ phosphate (Cukic, 2012; Cukic and Venter, 2010; Harding, 2004; Elvin and Cukic, 2010). Under certain conditions this phosphate will be released from the sediment back into the water column.

\section{Proposed solution}

Phosphate removal plants can be constructed near the three inflows to the dam, i.e., Crocodile River, Magalies River and the Swart Spruit. In the case of iron-rich mine water, a pipeline (150 mm diam.) needs to be laid to transfer acid mine water directly from the decant point at 18 Winze, near Krugersdorp, to the Crocodile River inlet. The pipeline can run via the Tweelopie Spruit $\rightarrow$ Bloubank Spruit $\rightarrow$ Crocodile River to the dam. Phosphate sludge can settle in the mouth of the Crocodile River. The settled sludge and sediment accumulated over time can be removed with a dredging system. Since water in the dam has a residence time of 300 days, an improvement in phosphate levels will be observed after 300 days, together with an improvement in the eutrophication problem, provided that the water column is replaced homogenously and is holomictic. In areas of the dam where this may not be the case, i.e., below a certain critical depth where thermal stratification is likely to occur, artificial turbulent mixing may be required, using water under pressure, for example.

The purpose of this investigation was to:

- Compare the effectiveness of $\mathrm{FeCl}_{3}, \mathrm{FeCl}_{2}, \mathrm{AlCl}_{3}, \mathrm{CaCl}_{2}$ and $\mathrm{Ca}(\mathrm{OH})_{2}$ for removal of $\mathrm{PO}_{4}$

- Determine the cost of phosphate removal for this proposed solution

\section{METHODOLOGY}

The OLI ESP software (OLI, 2015) program was used to predict the water quality after treatment with (i) alkalis such as $\mathrm{Na}_{2} \mathrm{CO}_{3}$ and $\mathrm{NaOH}$, for removal of metals, and (ii) freeze crystallization to concentrate the brine to the level where $\mathrm{Na}_{2} \mathrm{SO}_{4} \cdot 10 \mathrm{H}_{2} \mathrm{O}$ crystallizes. The DOW WAVE (DOW, 2017) software program was used to predict reverse osmosis (RO) performance. OLI ESP software is an aqueous equilibrium chemistry estimator with an interactive and self-instructive interface for clarifying reactions and the ability to work with all kinds of common equilibrium reactions. It has a strong solution algorithm, expressive and easily understandable displays of results, and the ability to produce results in multiple formats according to different uses. The Stream Analyzer of the OLI software was used to perform single-point equilibrium calculations, multiple-point survey calculations for calculating a complete trend analysis for characteristics such as temperature, pressure, $\mathrm{pH}$ and composition effects, and simple mix and separation capability. The calculations provide liquidand solid-phase separations for a specialized model. 
Table 1. Compounds formed by the metal compounds used for the removal of $\mathrm{PO}_{4}{ }^{3-}$

\begin{tabular}{|c|c|c|c|c|}
\hline \multirow[t]{2}{*}{ Parameter } & \multicolumn{4}{|c|}{ Chemical } \\
\hline & $\mathrm{FeCl}_{3}$ & $\mathrm{FeCl}_{2}$ & $\mathrm{AlCl}_{3}$ & $\mathrm{CaOH}_{2}$ \\
\hline Chemical/P molar ratio & 1.0 & 1.0 & 1.0 & 1.0 \\
\hline Chemical dosage (mg/L) & 48.7 & 57.1 & 40.1 & 33.3 \\
\hline Initial $\mathrm{PO}_{4}{ }^{3-}$ (as P) (mg/L) & 9.3 & 9.3 & 9.3 & 9.3 \\
\hline Final $\mathrm{PO}_{4}^{3-}$ (as P) (mg/L) & 0.02 & 2.22 & 4.50 & 0.94 \\
\hline $\mathrm{pH}$ range & $<5.4$ & $7.8-9.1$ & $3.7-3.9$ & $>9.5$ \\
\hline First product & $\mathrm{FePO}_{4}$ (phospho-derite) & $\mathrm{Fe}_{3}\left(\mathrm{PO}_{4}\right)_{2}$ (vivianite) & $\mathrm{AIPO}_{4}$ (berlinite) & $\mathrm{Ca}_{3}\left(\mathrm{PO}_{4}\right)_{2}$ (hydroxy-apatite) \\
\hline Second product & $\mathrm{Fe}(\mathrm{OH})_{3}$ (bernalite) & $\mathrm{Fe}(\mathrm{OH})_{2}$ (amakinite) & $\mathrm{Al}(\mathrm{OH})_{3}$ (bayerite) & $\mathrm{CaCO}_{3}$ (calcite) \\
\hline
\end{tabular}

The OLI Analyser 9.0 System was used to simulate the reactions by running a simulated AMD sample with assumed values of temperature, pressure, and $\mathrm{pH}$. The base titrants used were $\mathrm{NaOH}, \mathrm{Na}_{2} \mathrm{CO}_{3}$ and $\mathrm{Ca}(\mathrm{OH})_{2}$. The temperature was assumed to be $25^{\circ} \mathrm{C}$ and the pressure, $101325 \mathrm{~Pa}(1 \mathrm{~atm})$. The $\mathrm{pH}$ was varied as desired with the different alkalis. Once the input values were run in the OLI Systems: Chem Analyzer, a calculated summary of the simulated results appeared. These could be used to predict the actual reactions to be used in the treatment methods according to the specific characteristics. Thus, it was used to optimize a neutralisation-precipitation-desalination process for acid mine drainage (AMD).

The results from OLI simulations were used as input to the WAVE software simulating RO feed water. The DOW WAVE design software is an integration of ultrafiltration, $\mathrm{RO}$ and ion-exchange that provides one comprehensive tool in a single common interface. Only proprietary DOW products are available for simulations.

Water analyses were obtained from Huizenga et al. (2013).

\section{RESULTS AND DISCUSSION}

The challenge of the removal of biogenic substances, such as phosphate, is a priority for enhanced quality of wastewater purification, and results in improved ecological health of the water environment. There are a variety of ways to remove phosphates from water: chemically, biologically, by modifying the biological processes that incorporate phosphorus into the cellular structure, or by biological-chemical methods. Chemical and physicochemical methods used to displace phosphorus are diverse and numerous. Chemical methods are generally avoided because of associated high costs of reactants and also because the use of coagulants generates secondary pollutants. Application of sorbents requires thorough pre-treatment of the liquid drainage, since the presence of suspension dredge and other pollutants in the water compromises the sorptive capacity of materials. This makes purification processes more complex and expensive. Biological methods of phosphorus removal are starting to be employed universally. If conducted correctly and appropriately, biological processes can remove phosphates efficiently, but in most cases fail to achieve stable removal of phosphate from drainage water, down to the regulated minimum concentration limit for, e.g., fish farming reservoir water. In practice, different systems are used that combine biological processes with chemical precipitation. This is the most promising combination, that not only ensures better quality water purification compared to either method used singly, but also makes the process more stable (Ruzhitskaya and Gogina, 2017; Bali and Gueddari, 2019). The method modelled and described in this paper is a chemical one and is, as discussed below, simpler and more cost-effective than the traditional lime treatment, which thus addresses the high costs associated with the use of lime.

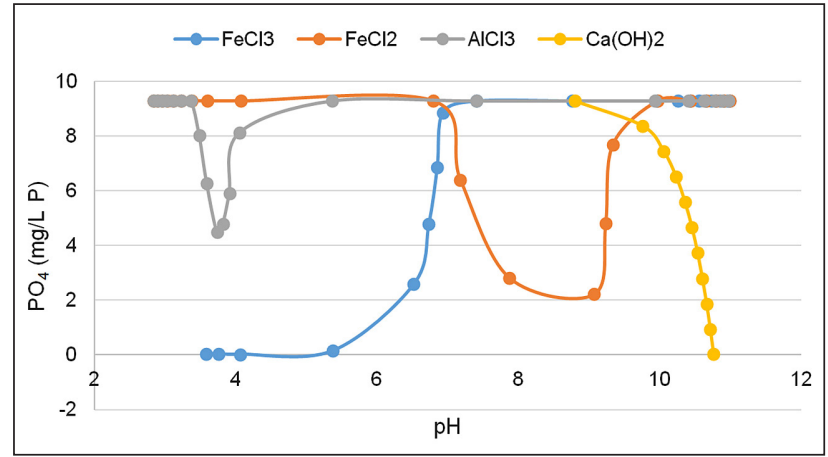

Figure 2. Effect of $\mathrm{pH}$ on $\mathrm{PO}_{4}^{3-}$ removal for $\mathrm{FeCl}_{3}, \mathrm{FeCl}_{2}, \mathrm{AlCl}_{3}$ and $\mathrm{Ca}(\mathrm{OH})_{2}\left(\mathrm{Na}_{2} \mathrm{HPO}_{4}=0.3 \mathrm{mmol} / \mathrm{L}(9.3 \mathrm{mg} / \mathrm{L} \mathrm{P}) ; \mathrm{H}_{2} \mathrm{SO}_{4}=1 \mathrm{mmol} / \mathrm{L}\right.$ $(98 \mathrm{mg} / \mathrm{L}) ; \mathrm{FeCl}_{3}=48.7 \mathrm{mg} / \mathrm{L} ; \mathrm{FeCl}_{2}=56.6 \mathrm{mg} / \mathrm{L} ; \mathrm{AlCl}_{3}=40.5 \mathrm{mg} / \mathrm{L} ;$ $\left.\mathrm{Ca}(\mathrm{OH})_{2}=33.3 \mathrm{mg} / \mathrm{L}\right)$

\section{Behaviour of various chemicals}

Chemical phosphate removal with iron-rich mine water, and commercially available iron(III), iron(II) aluminium(III) calcium(II) and $\mathrm{Ca}(\mathrm{OH})_{2}$, can be considered as low-cost solutions for phosphate removal. Figure 2 and Table 1 compare the suitability of various chemicals for removal of phosphate from $9.3 \mathrm{mg} / \mathrm{L}$ (as P) down to $1.0 \mathrm{mg} / \mathrm{L}$, as determined with OLI software. Important aspects are: (i) the concentration to which $\mathrm{PO}_{4}$ can be removed, and (ii) the $\mathrm{pH}$ range required. In all cases $9.3 \mathrm{mg} / \mathrm{L}$ $\mathrm{PO}_{4}^{3-}$ (as $\mathrm{P}$ ) was treated with stoichiometrically equal dosages of the various chemicals. $\mathrm{FeCl}_{3}(48.7 \mathrm{mg} / \mathrm{L})$ removed $\mathrm{PO}_{4}{ }^{3-}$ down to $<0.02 \mathrm{mg} / \mathrm{L}$ (as P) for $\mathrm{pH}$ values $<4.0 . \mathrm{FeCl}_{2}(56.6 \mathrm{mg} / \mathrm{L}$ ) could only remove $\mathrm{PO}_{4}$ from $9.3 \mathrm{mg} / \mathrm{L}$ down to $2.0 \mathrm{mg} / \mathrm{L}$ in the $\mathrm{pH}$ range 7.8-9.1. $\mathrm{AlCl}_{3}(40.5 \mathrm{mg} / \mathrm{L})$ only removed $\mathrm{PO}_{4}$ from $9.3 \mathrm{mg} / \mathrm{L}$ down to $4.5 \mathrm{mg} / \mathrm{L}$ in the narrow $\mathrm{pH}$ range of 3.7-3.9. $\mathrm{Ca}(\mathrm{OH})_{2}$ $\left(33.3 \mathrm{mg} / \mathrm{L}\right.$ ) removed $\mathrm{PO}_{4}{ }^{3-}$ down to $0.94 \mathrm{mg} / \mathrm{L}$ for $\mathrm{pH}$ values $>9.5$. With a slight excess and a higher $\mathrm{pH}, \mathrm{Ca}(\mathrm{OH})_{2}$ treatment can remove $\mathrm{PO}_{4}^{3-}$ down to even lower concentrations.

With $\mathrm{Ca}(\mathrm{OH})_{2}$ treatment phosphate was removed as $\mathrm{Ca}_{3}\left(\mathrm{PO}_{4}\right)_{2}$, with $\mathrm{FeCl}_{3}$ treatment as $\mathrm{FePO}_{4}$, with $\mathrm{FeCl}_{2}$ treatment as $\mathrm{Fe}_{3}\left(\mathrm{PO}_{4}\right)_{2}$ and with $\mathrm{AlCl}_{3}$ treatment as $\mathrm{AlPO}_{4}$. Other compounds that formed were: $\mathrm{CaCO}_{3}$ in the case of $\mathrm{Ca}(\mathrm{OH})_{2}$ (when $\mathrm{HCO}_{3}{ }^{-}$was present); $\mathrm{Fe}(\mathrm{OH})_{3}$ formed in the case of $\mathrm{FeCl}_{3}$ and $\mathrm{AlCl}_{3}$, and $\mathrm{Fe}(\mathrm{OH})_{2}$ in the case of $\mathrm{FeCl}_{2}$ treatment.

\section{Hartbeespoort Dam water}

From the above results it was clear that $\mathrm{Fe}$ and $\mathrm{Al}$ salts were unsuitable for $\mathrm{PO}_{4}{ }^{3-}$ removal, while $\mathrm{Ca}(\mathrm{OH})_{2}$ was found to be effective. Therefore, an OLI simulation was carried out on water similar in composition to Hartbeespoort Dam water. It was found that with a dosage of $50 \mathrm{mg} / \mathrm{L} \mathrm{Ca}(\mathrm{OH})_{2}, \mathrm{PO}_{4}{ }^{3-}$ was removed from water having $0.19 \mathrm{mg} / \mathrm{L}$ (as P) down to $<0.02 \mathrm{mg} / \mathrm{L}$ (as P) 
(Fig. 3 and Table 2). The $\mathrm{pH}$ of 8.7 after lime addition was still within specified discharge regulations of $\mathrm{pH}$ 5-9 (National Water Act No. 36 of 1998; RSA, 1998). A further benefit of lime usage was a reduction of alkalinity from $123 \mathrm{mg} / \mathrm{L}$ to $80 \mathrm{mg} / \mathrm{L}\left(\right.$ as $\mathrm{CaCO}_{3}$ ) as the result of $\mathrm{CaCO}_{3}$ precipitation.

The cost of lime treatment was estimated at $0.15 \mathrm{ZAR} / \mathrm{m}^{3}$ (Table 3). This calculation was based on a lime dosage of $50 \mathrm{mg} / \mathrm{L}$, a flow-rate of $650 \mathrm{ML} / \mathrm{d}$ and a lime price of $2500 \mathrm{ZAR} / \mathrm{t}$.

If phosphate can be removed down to less than $0.02 \mathrm{mg} / \mathrm{L}$ (as P), algal and water hyacinth growth will be eliminated, which will result in a dam with clear water.

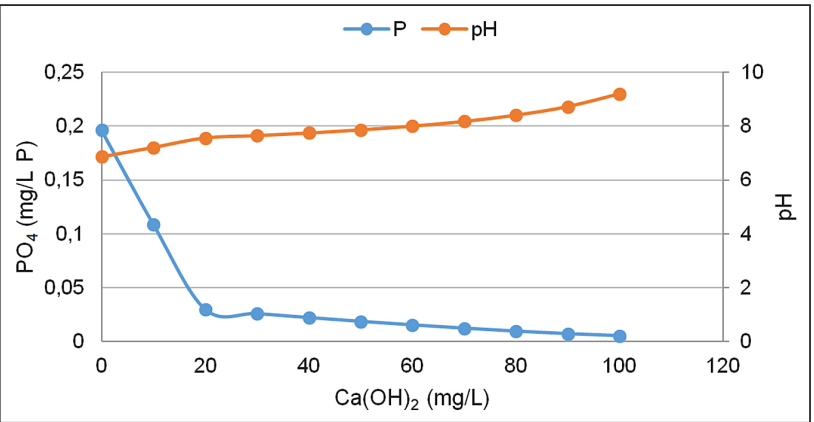

Figure 3. Effect of $\mathrm{Ca}(\mathrm{OH})_{2}$ dosage on $\mathrm{PO}_{4}{ }^{3-}$ removal from Hartbeespoort Dam water

Table 2. Chemical composition of Hartbeespoort Dam water before and after $\mathrm{Ca}(\mathrm{OH})_{2}$ treatment at dosage of $50 \mathrm{mg} / \mathrm{L}$

\begin{tabular}{|c|c|c|}
\hline \multirow[t]{2}{*}{ Parameter } & \multicolumn{2}{|c|}{ Water quality } \\
\hline & $\begin{array}{l}\text { HBP Dam } \\
\text { before }\end{array}$ & $\begin{array}{l}\mathrm{Ca}(\mathrm{OH})_{2} \\
\text { Treated }\end{array}$ \\
\hline \multicolumn{3}{|l|}{ Solution } \\
\hline $\mathrm{pH}$ & 6.86 & 7.86 \\
\hline $\mathrm{Cl}^{-}(\mathrm{mg} / \mathrm{L})$ & 57.8 & 57.8 \\
\hline $\mathrm{SO}_{4}^{2-}(\mathrm{mg} / \mathrm{L})$ & 84.4 & 84.4 \\
\hline $\mathrm{PO}_{4}^{3-}(\mathrm{mg} / \mathrm{LP})$ & 0.196 & 0.019 \\
\hline Alkalinity $\left(\mathrm{mg} / \mathrm{L} \mathrm{CaCO}_{3}\right)$ & 122.9 & 80.8 \\
\hline $\mathrm{Na}^{+}(\mathrm{mg} / \mathrm{L})$ & 46.8 & 46.8 \\
\hline $\mathrm{K}^{+}(\mathrm{mg} / \mathrm{L})$ & 7 & 7 \\
\hline $\mathrm{Mg}^{2+}(\mathrm{mg} / \mathrm{L})$ & 15 & 15 \\
\hline $\mathrm{Ca}^{2+}(\mathrm{mg} / \mathrm{L})$ & 37.9 & 30.9 \\
\hline Cations (meq/L) & 5.34 & 4.99 \\
\hline Anions (meq/L) & 5.86 & 5.01 \\
\hline \multicolumn{3}{|l|}{ Solids } \\
\hline $\mathrm{Ca}_{5}(\mathrm{OH})\left(\mathrm{PO}_{4}\right)_{3}$ (hydroxyapatite) & 0 & 0.96 \\
\hline $\mathrm{CaCO}_{3}$ (calcite) & 0 & 83.9 \\
\hline Calculated & & 85.07 \\
\hline
\end{tabular}

Table 3. Cost of $\mathrm{Ca}(\mathrm{OH})_{2}$ treatment

\begin{tabular}{lc}
\hline Parameter & Value \\
\hline $\mathrm{Ca}(\mathrm{OH})_{2}$ dosage $(\mathrm{mg} / \mathrm{L})$ & 50 \\
Purity $(\%)$ & 85 \\
Flow $(\mathrm{ML} / \mathrm{d})$ & 650 \\
Dam volume $(\mathrm{ML})$ & 234000 \\
$\mathrm{Ca}(\mathrm{OH})_{2}$ usage $(\mathrm{t} / \mathrm{d})$ & 38.24 \\
$\mathrm{Ca}(\mathrm{OH})_{2}$ usage $(\mathrm{t}$ for dam volume) & 13765 \\
$\mathrm{Ca}(\mathrm{OH})_{2}$ price $(\mathrm{ZAR} / \mathrm{t})$ & 2500 \\
$\mathrm{Cost}\left(\mathrm{ZAR} / \mathrm{m}^{3}\right)$ & 0.15 \\
$\mathrm{Ca}(\mathrm{OH})_{2}$ cost $(\mathrm{ZAR} / \mathrm{d})$ & 95588 \\
$\mathrm{Ca}(\mathrm{OH})_{2}$ cost $(\mathrm{ZAR}$ for dam volume) & 34411765 \\
\hline
\end{tabular}

The main innovation in the use of lime for removal of phosphate, is that lime is commercially available and widely used in water treatment. Lime will not only result in phosphate removal, but also in alkalinity lowering.

\section{Sediment and phosphate removal}

Chemical phosphate removal is recommended, and the preceding section has shown that lime treatment would be the most costeffective solution. Phosphate removal plants can be constructed near the three inflows to the dam, i.e., at the Crocodile River, Magalies River and Swart Spruit influences. Since the dam sediment contains more than $3000 \mathrm{t}$ of phosphate $\left(\right.$ as $\left.\mathrm{PO}_{4}\right)$, sediment removal through dredging is essential and must be implemented simultaneously with phosphate removal.

The mass of phosphate to be removed from the dam is calculated at $42 \mathrm{t} / \mathrm{a}$ (as P), i.e., (0.196-0.019) $\mathrm{mg} / \mathrm{L}$ x $650 \mathrm{ML} /$ day x 365 day/a and $1000 \mathrm{~kg} / \mathrm{t}$. New $\mathrm{Ca}_{2}\left(\mathrm{PO}_{4}\right)_{3}$ and existing sediment in the dam can be removed through dredging. By removing the phosphaterich sediment, the water storage capacity will increase by $15 \%$ and the sediment can be used as a good soil conditioner. Darmody and Diaz (2017) showed that sediment from the Peoria Lake portion of the Illinois River, in the USA, could be used to enhance sandy soils as sediments often have high nutrient levels and physical properties that are desirable for agricultural production.

\section{CONCLUSIONS}

The following conclusions were drawn from the present study:

1. $\mathrm{Ca}(\mathrm{OH})_{2}$ is the most suitable chemical for removal of phosphate as the $\mathrm{pH}$ only needs to be raised to $9.5 . \mathrm{FeCl}_{3}$ can remove phosphate to almost zero $\mathrm{mg} / \mathrm{L}$ but only for $\mathrm{pH}$ values $<5.4$.

2. $\mathrm{FeCl}_{2}$ treatment can only remove phosphate down to $2.2 \mathrm{mg} / \mathrm{L}$ within a narrow $\mathrm{pH}$ range of 7.8-9.1. $\mathrm{AlCl}_{3}$ can remove phosphate down to $4.5 \mathrm{mg} / \mathrm{L}$ within a very narrow $\mathrm{pH}$ range of 3.7-3.9.

3. With $\mathrm{Ca}(\mathrm{OH})_{2}$ treatment, phosphate is removed as $\mathrm{Ca}_{3}\left(\mathrm{PO}_{4}\right)_{2}$; with $\mathrm{FeCl}_{3}$ treatment, as $\mathrm{FePO}_{4}$; with $\mathrm{FeCl}_{2}$ treatment, as $\mathrm{Fe}_{3}\left(\mathrm{PO}_{4}\right)_{2}$; and with $\mathrm{AlCl}_{3}$ treatment, as $\mathrm{AlPO}_{4}$.

4. Other compounds that form are: $\mathrm{CaCO}_{3}$ in the case of $\mathrm{Ca}(\mathrm{OH})_{2}$ (when $\mathrm{HCO}_{3}{ }^{-}$is present); $\mathrm{Fe}(\mathrm{OH})_{3}$ in the case of $\mathrm{FeCl}_{3}$; and $\mathrm{AlCl}_{3}$ and $\mathrm{Fe}(\mathrm{OH})_{2}$ in the case of $\mathrm{FeCl}_{2}$.

5. For removal of phosphate from $0.19 \mathrm{mg} / \mathrm{L}$ (as P), the current concentration in the Hartbeespoort Dam, down to $<0.05$ $\mathrm{mg} / \mathrm{L}$ (as $\mathrm{P}$ ), the minimum concentration that is needed to support algal growth, a lime dosage of $50 \mathrm{mg} / \mathrm{L}$ is required.

6. The cost of lime treatment is estimated to amount to 0.15 $\mathrm{ZAR} / \mathrm{m}^{3}$.

In investigating the removal of phosphates from water, this computational study provides a partial contribution to providing sustainable water resources management in South Africa. Removal of phosphates is likely to eliminate or reduce eutrophication of water bodies, leading to preservation of aquatic life in surface waters. The sediments from the dam resulting from this in-situ treatment can be mined to recover phosphates for manufacture of fertilizers.

\section{RECOMMENDATIONS}

It is proposed that the findings from this simulation study be tested first at laboratory scale and subsequently at pilot-scale, where Hartbeespoort Dam water is passed through two $5 \mathrm{~m}^{3}$ ponds $\left(\right.$ depth $=1 \mathrm{~m}$; flow-rate $=0.1 \mathrm{~m}^{3} /$ day; HRT $=50$ days $)$. 
One pond can serve as the control with no lime addition. Lime can be dosed to the second pond to raise the $\mathrm{pH}$ to 9. Phosphate, algal growth and water-hyacinth growth need to be monitored for a period of 12 months.

\section{ACKNOWLEDGMENTS}

Tshwane University of Technology is acknowledged for funding this study. Dr Fritz Carlsson is thanked for proof-reading and editorial input.

\section{REFERENCES}

ANNANDALE J, BELETSE Y, STIRZAKER R and BRISTOW K (2011) Managing poor quality coal-mine water: Is irrigation part of the solution? In: Observations on Environmental Change in South Africa. Sun Press, Cape Town. 174-177.

BALI M and GUEDARI M (2019) Removal of phosphorus from secondary effluents using infiltration-percolation process. Appl. Water Sci. 9 Article 54. 8 pp. https://doi.org/10.1007/s13201-019-09 45-5

CHUTTER FM and ROSSOUW JN (1992) The management of phosphate concentrations and algae in Hartbeespoort Dam. WRC Report No. 289/1/91. Water Research Commission, Pretoria.

CREAMER T (2012) TCTA again warns of funding shortfall for acid water projects. Mining Weekly, 19 January 2012. URL: https:// www.engineeringnews.co.za/article/tcta-again-warns-of-fundingshortfall-for-acid-water-projects-2012-01-19.

CUKICZ (2012) Harties Metsi a Me Hartbeespoort Dam Bioremediation Programme, Sediment removal and management approach, goals, objectives, strategy. http://www.harties.org.za/documents/Sediment RemovalManagementStrategy2012.pdf (Accessed 10 July 2020).

CUKIC Z and VENTER P (2010) Characterization and managing of Hartbeespoort Dam internal nutrient load (sediments). In: Proceedings of the WISA Biennial Conference, 18-22 April 2010, Durban.

DARMODY RG and DIAZ DR (2017) Dredged sediment: application as an agricultural amendment on sandy soils. ISTC Reports. TR-066. Illinois Sustainable Technology Center, Champaign, Illinois. 102 pp.

DOW (2017) https://www.dow.com. URL: https://www.dow.com/en-us/ water-and-process-solutions/resources/design-software (Accessed October 2017).

DWS (Department of Water and Sanitation, South Africa) (2013) Hartbeespoort Dam Integrated monitoring programme: Phase 1 consolidated progress report. DWS, Pretoria.

RSA (Republic of South Africa) (1998). National Water Act. Act No. 36 of 1998. Government Gazette 19182. Government Printer, Cape Town.
ELVIN A and CUKIC Z (2010) Characterization of Hartbeespoort Dam sediment body. In: Proceedings of the WISA Biennial Conference, 18-22 April 2010, Durban.

FAO (Food and Agricultural Organisation, United Nations) (2018) World fertilizer trends and outlook to 2018. FAO, Rome.11-12.

GHASSEMI M and RECHT HL (1971) Phosphate precipitation with ferrous iron Series. Water Pollution Control Research Series 17010 EKI 09/71.

GRANT S, SAPHORES J, FELDMAN DL and MARUSIC I (2012) Taking the "waste" out of "wastewater" for human water security and ecosystem sustainability. Science. 337 (6095) 681-686. https:// doi.org/10.1126/science.1216852

HARDING WR (2004) Hartbeespoort Dam Remediation Project. Department of Water Affairs and Forestry, Somerset West.

HOLDSWORTH R (1991) New Health Considerations in Water Treatment. Avebury Technical, Aldershot.

HUIZENGA J, DENNIS RDI and SILBERBAUER M (2013) National data set $(1972$ - 2011) of rivers, dams and lakes in South Africa, Inorganic. Water Chem. 39 (2) 335-339. https://doi.org/10.4314/wsa. v39i2.18

HERRING JR and FANTEL JR (1993) Phosphate rock demand into the next century: Impact on world food supply. Nonrenewable Resour. 2 226-246. https://doi.org/10.1007/BF02257917

MITCHELL SA and CRAFFORD JG (2016) Review of the Hartbeespoort Dam integrated biological remediation programme (Harties Metsi a Me). WRC Report No. KV 357/16. Water Research Commission, Pretoria. 5-14

OBERHOLSTER PJ and ASHTON PJ (2008) State of the Nation Report. An overview of the current status of water quality and eutrophication in South African rivers and reservoirs. Parliamentary Grant Deliverable - March 2008

OLI (2015) OLI. http://www.olisystems.com/ (Accessed 23 November 2015).

RUZHITSKAYA O and GOGINA (2017) Methods for removing of phosphates from wastewater. MATEC Web of Conferences. 106 07006. https://doi.org/10.1051/matecconf/201710607006

USGS (United States Geological Survey) (2009) Mineral Commodity Summaries: Phosphate Rock. USGS, Reston, Virginia.

VAN DER MERWE PH, MAREE JP and BASSON ND (1983) Using acid mine water for removal of phosphates from sewage effluent. Water Sci. Technol. 15 (2) 155-167. https://doi.org/10.2166/wst.1983.0031

VENTER PJ (2004) New hope for troubled waters: The Hartbeespoort Dam test case, eutrophication management. The Water Wheel. 3 (1) $16-19$. 